\title{
PENGGUNAAN GOOGLE FORMS SEBAGAI MEDIA PEMBELAJARAN DARING DI MASA PANDEMI COVID-19 PADA MATA PELAJARAN SEJARAH DI SMK NEGERI 2 KETAPANG
}

\section{USE OF GOOGLE FORMS AS A MEDIA FOR ONLINE LEARNING IN THE PANDEMIC TIME COVID-19 IN HISTORICAL LESSONS AT SMK NEGERI 2 KETAPANG}

\author{
Fajar Heryadi \\ Sekolah Menengah Kejuruan Negeri 2 Ketapang \\ Email: fajarheryadi26@gmail.com
}

\begin{abstract}
Abstrak : Penulisan Best Practice ini bertujuan untuk mendeskripsikan pemanfaatan google forms sebagai media pembelajaran daring di masa pandemi covid-19 pada mata pelajaran sejarah di SMK Negeri 2 Ketapang. Subjek penulisan Best Practice ini adalah siswa kelas X di SMK Negeri 2 Ketapang Tahun Pelajaran 2020/2021. Penulisan Best Practice ini menggunakan metode deskriptif. Pemanfaatan Google forms sebagai media pembelajaran daring di masa pandemi covid-19 pada mata pelajaran sejarah di SMK Negeri 2 Ketapang pada topik Pengaruh Agama dan Kebudayaan Islam di Indonesia berlangsung efektif dengan prosentase siswa yang mengikuti kegiatan pembelajaran daring sebesar $90 \%$. Penilaian pengetahuan siswa pada pembelajaran sejarah secara daring ini disusun dengan menggunakan aplikasi google form dalam bentuk soal pilihan ganda melalui google forms. Terjadi peningkatan persentase angka ketuntasan hasil belajar siswa sebesar 30\% sebelum dan sesudah menggunakan aplikasi google forms. Sebelum pembelajaran daring menggunakan aplikasi google forms, siswa yang nilai pengetahuannya tuntas KKM hanya $50 \%$. Setelah dilakukan pembelajaran daring menggunakan aplikasi google forms meningkat sebesar 30\% yaitu mencapai $80 \%$.
\end{abstract}

Kata kunci: pembelajaran daring, google forms, Covid-19

\begin{abstract}
This Best Practice writing aims to describe the use of Google forms as an online learning medium during the Covid-19 pandemic in history subjects at SMK Negeri 2 Ketapang. The subjects of this Best Practice writing are class X students at SMK Negeri 2 Ketapang for the 2020/2021 academic year. This Best Practice writing uses descriptive method. The use of Google forms as an online learning medium during the Covid-19 pandemic in history subjects at SMK Negeri 2 Ketapang on the topic of The Influence of Religion and Islamic Culture in Indonesia was effective with a percentage of students participating in online learning activities of $90 \%$. Assessment of student knowledge in online history learning is compiled using the googlee form application in the form of multiple choice questions via google forms. There was an increase in the percentage of student learning outcomes by $30 \%$ before and after using the google forms application. Before online learning using the google forms application, students whose KKM complete knowledge score was only 50\%. After doing online learning using the google forms application, it increased by $30 \%$, reaching $80 \%$.
\end{abstract}

Keywords: online learning, google forms, Covid-19 


\section{PENDAHULUAN}

Indikator keberhasilan pembangunan suatu negara salah satunya adalah keberhasilan dalam bidang pendidikan. Melalui pendidikan, maka akan tercipta generasi penerus yang cerdas intelektual, jujur, terampil, dan mandiri untuk mencapai pembangunan bangsa ini. Namun dengan adanya Pandemi Covid-19 menciptakan persoalan yang cukup pelik bagi dunia pendidikan. Akibatnya, proses belajar mengajar di kelas jadi terganggu. Dampak yang dihasilkan dari permasalahan ini juga memengaruhi kualitas pendidikan yang sedang berjalan. Tidak hanya itu, dampaknya juga disinyalir akan berpengaruh pada arah kebijakan pendidikan Indonesia beberapa tahun ke depan.

Kondisi wabah pandemi Covid-19 ini mengakibatkan perubahan yang luar biasa bidang pendidikan. Seluruh jenjang pendidikan baik dari tingkat dasar sampai pada perguruan tinggi bertransformasi untuk beradaptasi secara tiba-tiba untuk melakukan pembelajaran secara daring (online). Ini tentu bukanlah hal yang mudah, karena belum sepenuhnya siap. Permasalahan yang ada di dunia pendidikan yaitu belum seragamnya proses pembelajaran, baik standar maupun kualitas capaian pembelajaran yang diharapkan.

Terjadinya pandemi Covid-19 telah memberikan gambaran ke depan atas keberlangsungan dunia pendidikan melalui perkembangan teknologi. Namun, kecanggihan teknologi tetap tidak akan dapat menggantikan peran guru, dan interaksi belajar antara pelajar dan pengajar sebab pendidikan bukan hanya sekedar memperoleh pengetahuan tetapi juga tentang nilai, kerja sama, karakter serta kompetensi. Kondisi pandemi ini menjadi tantangan tersendiri bagi guru dalam menggunakan teknologi untuk mengembangkan dunia Pendidikan.

Setelah adanya pandemi Covid-19 yang terjadi di hampir diseluruh wilayah Indonesia. Pemerintah menerapkan kebijakan yaitu Work From Home (Bekerja Dari Rumah). Kebijakan ini merupakan cara yang diterapkan kepada masyarakat agar dapat melakukan berabgai pekerjaan di rumah agar terhindar dari penularan virus Covid-19. Sektor Pendidikan di Indonesia pun menjadi salah satu bidang yang terdampak akibat adanya pandemi covid-19 tersebut. Kementerian Pendidikan dan Kebudayaan juga mengeluarkan kebijakan untuk proses kegiatan belajar dan mengajar selama masa pandemi yang dilakukan dengan menggunakan sistem pembelajaran secara daring dari rumah.

Melalui Surat Edaran Nomor 4 Tahun 2020 Kementerian Pendidikan dan Kebudayaan Republik Indonesia tentang proses belajar dari rumah dialksanakan dengan ketetentuan sebagai berikut : (1) Belajar dari rumah melalui pembelajaran daring/jarak jauh dilaksanakan untuk Jurnal Swadesi, Volume II Nomor 1 (Mei) 2021 
memberikan pengalaman belajar yang bermakna bagi peserta didik tanpa terbebani tuntutan menuntaskan seluruh capaian kurikulum untuk kenaikan kelas maupun kelulusan. (2) Belajar dari rumah dapat difokuskan pada pendidikan kecakapan hidup antara lain mengenai pandemi Covid-19. (3) Aktivitas dan tugas pembelajaran dari rumah dapat bervariasi antarpeserta didik, sesuai dengan minat dan kondisi masing-masing termasuk mempertimbangkan akses/fasilitas belajar di rumah. (4) Bukti atau aktifitas belajar dari rumah diberi umpan balik yang bersifat kualitatif dan berguna dari guru tanpa diharuskan memberi skor / nilai kuantitatif.

Belajar dari rumah merupakan kebijakan yang diambil oleh pemerintah untuk mencegah semakin meluasnya penyebaran Covid-19. Namun, dalam pelaksanaannya ditemukan beberapa masalah yang muncul ke permukaan. Beberapa masalah tersebut di antaranya adalah jaringan tidak lancar dan kuota internet yang memberatkan bagi peserta didik dan guru. Hal tersebut menandakan kendala yang dihadapi oleh peserta didik dan guru dalam melakukan pembelajaran daring. Selain itu, bagi guru terdapat tantangan lainnya, yakni guru kurang siap dalam menghadapi sistem pembelajaran daring yang saat ini diterapkan, karena dalam masa pandemi saat ini guru dipaksa untuk melakukan pembelajaran daring. Dengan melaksanakan kegiatan pembelajaran secara daring ini, muncul berbagai masalah yang dihadapi oleh siswa dan juga guru, seperti materi pelajaran yang tidak dapat disampaikan secara maksimal oleh guru. Banyaknya tugas yang diberikan oleh guru. Hal tersebut menjadi keluhan bagi siswa dalam mengikuti pembelajaran daring tersebut.

Berdasarkan permasalahan tersebut, maka diperlukan media yang dapat memberikan kemudahan bagi siswa dan guru dalam melaksanakan pembelajaran daring. Seperti kondisi yang terjadi saat ini, di mana para guru perlu beradaptasi dengan media pembelajaran melalui aplikasi internet untuk tetap melanjutkan kegiatan belajar mengajar di rumah akibat wabah virus covid-19. Ada banyak pilihan media yang dapat digunakan oleh guru selama melakukan pembelajaran daring di amsa pandemi ini. Aplikasi yang tersedia dari yang gratis hingga pada aplikasi yang harus banyak mengeluarkan biaya. Salah satu aplikasi yang dapat digunakan sebagai media pembelajaran daring secara gratis adalah google forms.

Google forms meruapkan aplikasi yang memiliki banyak fungsi bagi khususnya bagi dunia pendidikan antara lain: (1) sebagai media untuk pemberian tugas latihan/ulangan secara online, ruang berbagi data anatara guru dan siswa melalui halaman website, membuat formulir pendaftaran peserta didik baru secara online bagi sekolah/madrasah, berbagi kuisioner/amgket 
pada orang-orang secara online, mengumpulkan pendapat orang lain melalui laman website. Google forms merupakan bagian dari Google Suite For Education.

Sebagai sebuah aplikasi google forms dapat digunakan dalam melakukan proses pembelajaran secara daring selama masa pandemi. Adapun kelebihan menggunakan google forms adalah guru dapat memasukkan materi dalam bentuk dokumen, gambar maupun video pembelajaran. Guru juga dapat melaksanakan proses evaluasi pembelajaran secara online dengan membuat soal/tes bentuk pilihan ganda maupun uraian melaui google forms. Guru nantinya dapat melihat nilai siswa dengan cepat sehingga dapat melaksanakan tindak lanjut berupa remedial dan pengayaan. Untuk daftar hadir siswa juga bisa dipantau setiap harinya. Guru juga dapat mengecek kehadiran siswa yang masuk pada mata pelajaran dengan cara membuat absensi online melalui google forms. Dengan menggunakan google forms guru dapat memanfaatkan fitur analytics diagram, spreedsheat dan lainnya yang dapat digunakan untuk merekap data siswa.

Selama masa pandemi covid-19 proses pembelajaran di SMK Negeri 2 Ketapang dilaksanakan secara dalam jaringan (Daring) dan luar jaringan (Luring). Dalam melakukan pembelajaran daring ada yang dari rumah masing-masing, ada juga yang melakukan pembelajaran daring dari sekolah, dikarenakan ada siswa yang tidak memiliki perangkat android dan tidak memiliki kuota internet. Ada sekitar 90\% siswa yang melakukan pembelajaran daring dari rumah, sisanya mereka datang ke sekolah. Untuk memaksimalkan pembelajaran daring, guru-guru di SMK Negeri 2 Ketapang memanfaatkan berbagai aplikasi digital yang mudah untuk digunakan oleh siswa. Adapun aplikasi yang digunakan seperti , Google forms, Google Classroom, quizziz, zoom, google meet dan lainnya.

Penulisan best practised ini akan mendeskripsikan pengalaman mengajar penulis dengan menggunakan Google forms pada Kelas X pada mata pelajaran Sejarah di SMK Negeri 2 Ketapang. Permasalahan tersebut semakin menantang bagi guru sejarah ketika menghadapi masa pandemi saat ini, karena guru sejarah harus memaksimalkan fasilitas yang ada untuk membuat pembelajaran sejarah secara daring menjadi menarik. Dengan adanya tantangan yang diuraikan di atas, muncul pula peluang bagi guru sejarah selama masa pandemi ini untuk menciptakan pembelajaran sejarah yang menarik bagi siswa.

Google forms merupakan bagian dari platform google yang memungkinkan seseorang untuk membuat survey, tanya jawab dengan fitur formulir online yang dapat dibuat sesuai dengan kebutuhan. Menurut Wibawanto (2020) Google forms merupakan aplikasi google yang Jurnal Swadesi, Volume II Nomor 1 (Mei) 2021 
berfungsi untuk membuat formulir baik untuk pengumpulan informasi maupun kuis secara online.

Aplikasi Google forms dipilih sebagai media pembelajaran dan digunakan dalam pembelajaran sejarah karena guru pernah mengikuti workshop pemanfaatab media Google forms dalam pembelajaran. Penggunaan media tersebut juga lebih banyak digunakan oleh guru dibandingkan aplkasi yang lainnya, dikarenakan kemudahan dalam proses pembuatan dan penggunaan. Sehingga jika ada kendala teknis penggunaan bisa bertanya pada guru yang lain yang lebih menguasai penggunaan google forms tersebut.

Berdasarkan latar belakang di atas, maka rumusan masalah yang akan dikaji adalah Bagaimanakah pemanfaatan Google forms sebagai media pembelajaran daring di masa pandemi covid-19 pada mata pelajaran sejarah di SMK Negeri 2 Ketapang. Secara khusus penulisan Best Practice ini bertujuan untuk mengetahui : (1) Perencanaan pemanfaatan Google forms sebagai media pembelajaran daring di masa pandemi covid-19 pada mata pelajaran sejarah di SMK Negeri 2 Ketapang. (2) Pelaksanaan pemanfaatan Google forms sebagai media pembelajaran daring di masa pandemi covid-19 pada mata pelajaran sejarah di SMK Negeri 2 Ketapang. (3) Kendala dan solusi dalam pemanfaatan Google forms sebagai media pembelajaran daring di masa pandemi covid-19 pada mata pelajaran sejarah di SMK Negeri 2 Ketapang.

\section{METODE}

Penulisan Best Practice yang berjudul pemanfaatan Google forms sebagai media pembelajaran daring di masa pandemi covid-19 pada mata pelajaran sejarah di SMK Negeri 2 Ketapang ini menggunakan metode deskriptif. Menurut Nazir (1988: 63) metode deskriptif merupakan suatu metode penelitian untuk meneliti status sekelompok manusia, suatu objek, suatu set kondisi, suatu sistem pemikiran ataupun suatu kelas peristiwa pada masa sekarang. Penelitian deskriptif ini bertujuan untuk membuat deskripsi, gambaran, atau lukisan secara sistematis, faktual dan akurat mengenai fakta-fakta, sifat-sifat serta hubungan antarfenomena yang diselidiki. Menurut Sugiyono (2005: 21) metode deskriptif adalah suatu metode yang digunakan untuk menggambarkan atau menganalisis suatu hasil dari suatu penelitian tetapi tidak digunakan untuk membuat kesimpulan yang lebih luas lagi. 


\section{HASIL DAN PEMBAHASAN}

Pemerintah Provinsi Kalimantan Barat mengeluarkan kebijakan melalui surat edaran agar proses kegiatan belajar mengajar di tingkat SMA / SMK tetap berlangsung selama masa pandemi covid 19 dengan cara pembelajaran jarak jauh di rumah oleh siswa dan guru. Pembelajaran jarak jauh yang dilakukan dapat dilakukan secara daring (dalam jaringan) maupun luring (luar jaringan). Dalam pelaksanaan pembelajaran daring guru dapat menerapakan metode dengan aplikasi dan caranya masing masing yang dianggap efektif.

Istilah daring merupakan kepanjangan dari "dalam jaringan" yaitu suatu kegiatan yang dilaksanakan dengan sistem daring dengan memanfaatkan jaringan internet. Menurut Bilfaqih \& Qomarudin (2015:1) mengemukakan pembelajaran daring merupakan program penyelenggaraan kelas dalam jaringan untuk menjangkau kelompok target yang masif dan luas". Thorme dalam Kuntarto (2017:102) menyatakan pembelajaran daring adalah pembelajaran yang menggunakan teknologi multimedia, kelas virtual, CD ROM, streaming video, pesan suara, email dan telepon konferensi, teks online animasi, dan video streaming online. Sementara itu Alimuddin, Tawany \& Nadjib (2015:338) menekankan bahwa pemeblajaran daring merujuk pada penggunaan teknologi internet untuk mengirimkan serangkaian solusi yang dapat meningkatkan pengetahuan dan keterampilan.

Menurut Kartika (2018:27) mengatakan bahwa pembelajaran daring memberikan metode pembelajaran yang efektif, seperti berlatih dengan adanya umpan balik terkait, menggabungkan kolaborasi kegiatan dengan belajar mandiri, personalisasi pembelajaran berdasarkan kebutuhan peserta didik, menggunakan simulasi dan juga permainan. Sementara itu menurut Permendikbud No. 109/2013 pendidikan jarak jauh adalah suatu proses belajar mengajar yang dilakukan secara jarak jauh melalui penggunaan berbagai berbagai media komunikasi.

Guru-guru di SMK Negeri 2 Ketapang dalam melaksanakan proses pembelajaran secara daring menggunakan berbagai aplikasi digital yang ada agar materi pembelajaran dan proses pembelajaran dapat berlangsung dan juga siswa dapat menerima materi pembelajaran dengan baik. Berbagai aplikasi yang dapat memfasilitasi proses pembelajaran dan pendidikan di gunakan antara lain malalui Aplikasi Google Classroom, Zoom, Whatshap, Youtube, , Google forms dan aplikasi lainnya.

Menindaklanjuti aturan tersebut, penulis selaku guru pengampu mata pelajaran Sejarah Indonesia melakukan pembelajaran secara daring berdasarkan jadwal mengajar yang telah Jurnal Swadesi, Volume II Nomor 1 (Mei) 2021 
disusun agar siswa dapat menguasai semua kompetensi mata pelajaran Sejarah Indonesia di Kelas X SMK Negeri 2 Ketapang untuk semester ganjil tahun pelajaran 2020/2021 selama masa pandemi covid19.

Adapun aplikasi yang digunakan dalam pembelajaran sejarah secara daring di SMK Negeri 2 Ketapang adalah mengunakan Google forms. Selain aplikasi ini mudah digunakan, aplikasi ini juga dapat menjadi salah satu alternatif kegiatan evaluasi pembelajaran dengan metode daring. Google forms adalah aplikasi tanpa berbayar yang disediakan oleh google yang dapat digunakan untuk menyusun tes online secara cepat dan mudah. Beberapa fasilitas yang disediakan oleh google forms, yaitu mendesain formulir online untuk kuis dan ulangan harian dengan berbagai pilihan bentuk pertanyaan yang berbeda. Pengguna dapat memodifikasi google forms dengan menggunakan fitur template, membagikan google forms yang telah dibuat, menempelkan form tes/ujian online yang telah dibuat dalam blog atau website.

Adapun manfaat menggunakan Google forms Menurut David Wijaya (2020) : (1) Dapat menghemat pengeluaran. Dengan menggunakan Google forms dan dibagikan secara online, pengguna tidak perlu lagi mencetak survei menggunakan kertas. Dengan demikian, kita dapat menghemat penegeluaran berupa kertas dan tinta. (2) Dapat menghemat waktu dan tenaga. Google forms dapat dibagikan menggunakan email atau link kepada orang lain. Pengguna tidak perlu beranjak dari komputer atau smartphone Anda untuk membagikan survei tersebut. Dengan demikian, pengguna tidak perlu lagi mendatangi responden satu-persatu untuk meminta mengisi survei secara manual. Hal ini tentu menghemat waktu dan tenaga secara signifikan. (3) Data dapat tersimpan secara aman. Setiap forms yang dibuat dan setiap jawaban dari responden akan otomatis tersimpan pada Google Drive. Karena tersimpan di Google Drive, maka pengguna tidak perlu takut data-data hilang atau terhapus.

Perencanaan pembelajaran sejarah secara daring dengan media google forms kepada siswa diawali dengan membuat Rencana Pelaksanaan Pembelajaran (RPP) Daring mengunakan media Google forms. Salah satu tema/topik yang di bahas dalam pembelajaran sejarah tersebut adalah tentang Pengaruh Agama dan Kebudayaan Islam di Indonesia. Berdasarkan topik tersebut diharapkan siswa dapat menguasai materi tentang: (1) Teori masuk dan berkembangnya Islam di Indonesia (2) Bukti-bukti awal penyebaran Islam di Indonesia (3) Kerajaan-kerajaan Islam di Indonesia (4) Bukti-bukti pengaruh Islam di Indonesia

Saya sebagai guru sejarah menerapkan model pembelajaran discovery learning dengan metode diskusi, tanya jawab dalam pelaksanaan pembelajaran sejarah menggunakan Google Jurnal Swadesi, Volume II Nomor 1 (Mei) 2021 
forms sebagai media pembelajaran daring di masa pandemi covid-19 pada mata pelajaran sejarah di SMK Negeri 2 Ketapang agar tujuan pembelajaran tersebut dapat tercapai,.

Pembelajaran di awali dengan membuka Whatsapp Grup kelas. Selanjutnya mengucapkan salam, mengisi daftar hadir melalui google forms, guru meminta siswa berdoa terlebih dahulu, selanjutnya guru menyampaikan tujuan pembelajaran, apersepsi dan memberikan motivasi. Selain itu guru juga mengingatkan siswa untuk senantiasa menerapkan perilaku 3M yaitu memakai masker, menjaga jarak, dan mencuci tangan agar terhindar dari penularan virus covid 19. Pada kegiatan inti pembelajaran guru terlebih dahulu mengirimkan link materi pembelajaran di google forms. Kemudian guru memberikan pertanyaan kepada siswa terkait materi yang dibahas. Kemudian guru meminta siswa untuk mencari jawaban dengan mengumpulkan dan mengolah data dari berbagai sumber belajar. Setelah itu siswa dapat memberikan jawabannya langsung di google forms terhadap pertanyaan yang telah diberikan. Selanjutnya, guru memberikan memeriksa dan memberikan masukan terhadap setiap jawaban siswa. Pada kegiatan penutup, guru mengemukakan kembali pokok-pokok materi yang telah dipelajari agar siswa memperoleh gambaran yang utuh tentang materi dan hasil belajar yang telah mereka pelajari. Selanjutnya siswa mengerjakan soal evaluasi memngunakan aplikasi google forms melalui link yang telah dibagikan di Whatsaap Grup Kelas.

Selama pembelajaran daring melalui media google forms menunjukkan bahwa penggunaan google forms sebagai media pembelajaran daring di masa pandemi covid-19 pada mata pelajaran sejarah di SMK Negeri 2 Ketapang menunjukkan peningkatan aktivitas belajar peserta didik dari sebelumnya. Sebelum menggunakan aplikasi google forms persentase aktivitas belajar daring peserta didik hanya sebesar 55\%. Sebagian besar peserta didik tidak aktif atau enggan mengikuti pembelajaran daring karena dirasa membosankan dan membebani. Setelah menggunakan aplikasi google forms aktivitas belajar peserta didik meningkat 55\% menjadi 90\%. Peserta didik sangat antusias mengikuti pembelajaran karena tampilannya lebih menarik, mudah digunakan dan hemat kuota. Peningkatan aktivitas peserta didik dalam pembelajaran, dinyatakan dengan persentase. 


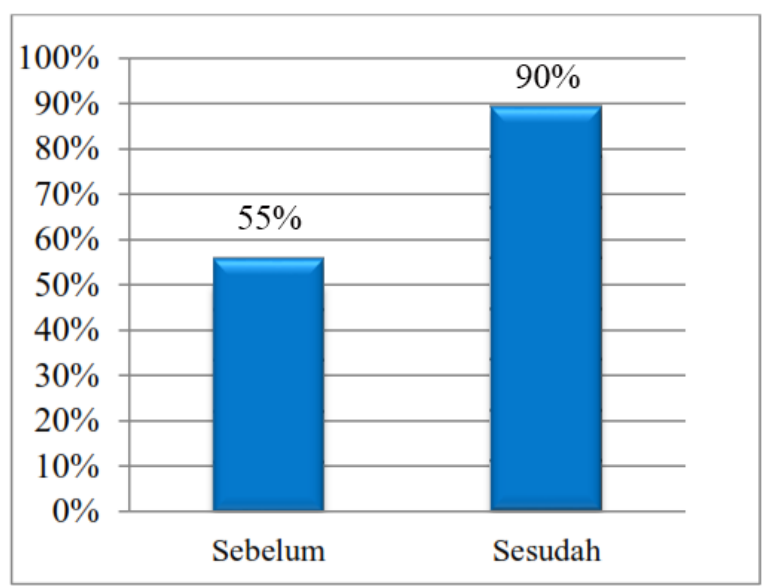

Gambar 1. Diagram Aktivitas Belajar Sesudah Mengguanakan Google Form

Selain aktivitas belajar peserta didik, hasil belajar ssiwa pada aspek pengetahuan sebelum dan sesudah penggunaan aplikasi google forms juga meningkat. Terjadi peningkatan persentase angka ketuntasan hasil belajar siswa sebesar $30 \%$ sebelum dan sesudah menggunakan aplikasi google forms. Sebelum pembelajaran daring menggunakan aplikasi google forms, sswa yang nilai pengetahuannya tuntas KKM hanya 50\%. Setelah dilakukan pembelajaran daring menggunakan aplikasi google forms meningkat sebesar $30 \%$ yaitu mencapai $80 \%$. Adapun grafik peningkatan ketuntasan hasil belajar siswa sebelum dan sesudah menggunakan google forms sebagai media pembelajaran daring di masa pandemi covid-19 pada mata pelajaran sejarah di SMK Negeri 2 Ketapang dilihat pada gambar berikut :

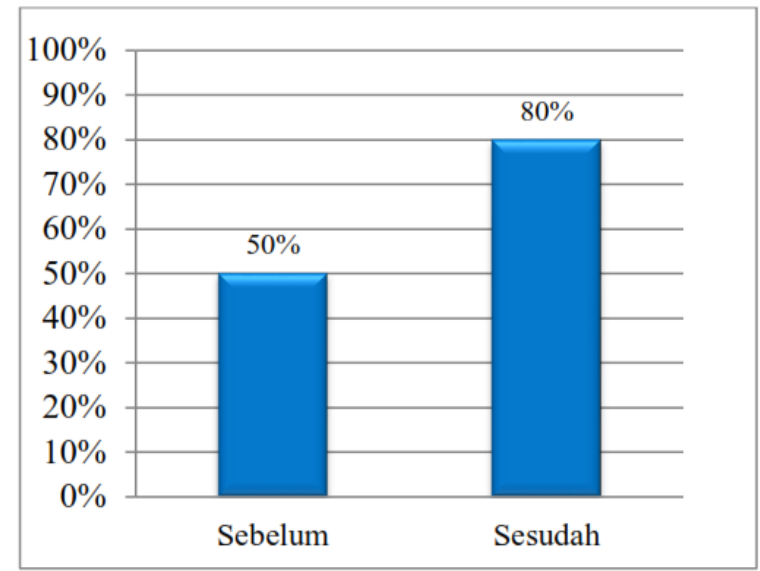

Gambar 2. Diagram Hasil Belajar Sesudah Mengguanakan Google Form

Selain dampak positif, ada juga kendala yang dihadapi oleh siswa selama mengikuti pembelajaran daring dengan mengguankan media google forms, antara lain: (1) Masih terdapat siswa yang bertempat tinggal di wilayah kecamatan dengan kondisi jaringan koneksi internet yang kurang baik, sehingga kesulitan untuk dapat mengakses tugas yang diberikan secara Jurnal Swadesi, Volume II Nomor 1 (Mei) 2021 
daring (online). (2) Terdapat beberapa siswa yang berasal dari keluarga ekonomi tidak mampu yang tidak bias membeli paket kuota internet. (3) Siswa mengeluhkan banyaknya tugas yang diberikan oleh guru-guru pada pembelajaran secara daring. (4) Adanya kesulitan untuk memastikan apakah siswa benar-benar mengerjakan tugas sendiri berdasarkan pemahamannya sendiri. (5) Guru tidak bisa mengamati secara langsung kegiatan peserta didik sehingga sulit untuk menilai kepribadian mereka dikarenakan tidak adanya proses pembelajaran secara tatap muka seperti biasanya.

Adapun hal yang bisa dilakukan sebagai solusi dari kendala yang dihadapi selama pembelajaran daring ke depannya antara lain: (1) Bagi siswa yang tidak bisa mengikuti pembelajaran secara daring, maka diberikan pembelajaran secara luring dengan memberikan bahan belajar yang dapat diambil oleh siswa di sekolah (2) Adanya bantuan pembelian kuota internet dari pemerintah/sekolah agar meringankan beban siswa. (3) Guru dapat mengunjungi langsung siswa di rumah untuk bisa mengamati secara langsung perkembangan perilaku mereka. (4) Kepala sekolah dapat memberikan arahan dan pengawasan lebih intensif lagi, agar guru memberikan tugas yang tidak monoton dan membebani siswa selama pembelajaran daring.

\section{SIMPULAN}

Pemanfaatan google forms dalam pembelajaran secara daring di masa pandemi covid-19 pada mata pelajaran sejarah di SMK Negeri 2 Ketapang pada topik Pengaruh Agama dan Kebudayaan Islam di Indonesia berlangsung secara efektif dengan prosentase siswa yang mengikuti kegiatan pembelajaran daring sebesar 90\%. Pelaksanaan evaluasi pembelajaran sejarah secara daring ini disusun dengan menggunakan aplikasi google forms dalam bentuk soal pilihan ganda. Terjadi peningkatan persentase angka ketuntasan hasil belajar siswa sebesar 30\% sebelum dan sesudah menggunakan aplikasi google forms. Sebelum pembelajaran daring menggunakan aplikasi google forms, siswa yang nilai pengetahuannya tuntas KKM hanya 50\%. Setelah dilakukan pembelajaran daring menggunakan aplikasi google forms meningkat sebesar 30\% yaitu mencapai $80 \%$. Maka dapat disimpulkan bahwa Pemanfaatan Google forms sebagai media pembelajaran daring di masa pandemi covid-19 pada mata pelajaran sejarah di SMK Negeri 2 Ketapang cukup efektif. 


\section{DAFTAR PUSTAKA}

Alimuddin., Tawany Rahamma., M. Nadjib. (2015). "Intensitas Penggunaan E-Learning Dalam Menunjang Pembelajaran Mahasiswa Program Sarjana (S1) Di Universitas Hasanuddin". Jurnal Komunikasi KAREBA, 4(4).

Bilfaqih, Y., Qomarudin, M.N. (2015). Esensi Penyusunan Materi Daring Untuk Pendidikan Dan Pelatihan. Yogyakarta: DeePublish

Eko Kuntarto (2017). "Kefektifan Model Pembelajaran Daring Dalam Perkuliahan Bahasa Indonesia Diperguruan Tinggi”. Journal Indonesian Language Education and Literature / ILE\&E/Vol.3 No. 1

Kartika, A. R. (2018). “Model Pembelajaran Daring”. Journal of Early Childhood Care \& Education

Nazir. (1988). Metodologi Penelitian. Jakarta: Ghalia Indonesia

Sugiyono. (2005). Metode Penelitian Kuantitatif Kualitatif dan R\&D. Bandung: Alfabeta.

Wibawanto. (2020). Pemanfaatan Googleform Sebagai Media Pembelajaran Jarak Jauh Atasi Penyebaran Covid-19. http://lpmplampung.kemdikbud.go.id. (Online)

Wijaya, D. (2020). Kelebihan dan Kekurangan Google forms. https://www.nitrotekno. com/kelebihan-kekurangan-google-form/. (Online) 